\title{
A Gel-stabilized Model Ecosystem for Investigating Microbial Growth in Spatially Ordered Solute Gradients
}

\author{
By J. W. T. WIMPENNY,* J. P. COOMBS, R. W. LOVITT AND \\ S. G. WHITTAKER \\ Department of Microbiology, University College, Cardiff, Newport Road, \\ Cardiff CF2 ITA, U.K.
}

(Received 29 September 1980; revised 1 April 1981)

\begin{abstract}
The structured nature of microbial ecosystems makes their study difficult, and simple laboratory analogues are needed. Two gel-stabilized gradient systems are described in which solute transfer is by diffusion alone. In the first, organisms grow in a semi-solid agar gel located above a source layer of full-strength agar containing the diffusible solute, which was glucose in the experiments reported here. Changes in physicochemical parameters, various solutes and cell concentration have been monitored in cultures of Bacillus megaterium NCTC 10342 and Lactobacillus confusus NCIB 4037 grown in this system. In experiments with a range of bacteria, banded growth was noted for several strains. The microbiology of the water at the base of an oil storage tank was investigated in the second model, in which gas oil was poured over a semi-solid layer containing agar, a basal salts medium, cells and a steel plate. After incubation for up to $90 \mathrm{~d}$ the system had differentiated into aerobic and anaerobic regions, and activities included hydrocarbon catabolism, oxygen removal, sulphate reduction, and the growth of a large population of aerobic and anaerobic heterotrophs. The value of these models is discussed with reference to microbial ecology.
\end{abstract}

\section{INT RODUCTION}

Virtually all investigations into microbial growth and physiology have employed pure or mixed cultures cultivated in homogeneous growth systems such as shake flasks or stirred fermenters. This homogeneity is rare in natural ecosystems, where organisms generally proliferate in spatially organized gradients of nutrients and solutes. Such habitats include stratified bodies of water (Deevey, 1951; Sorokin, 1968; Chebotarev et al., 1974); lake and estuarine sediments (Mortimer, 1942; Stanley \& Malcolm, 1980); algal mats (Jørgensen et al., 1979); soil profiles (Greenwood, 1971; Armstrong, 1975); mycelial balls and microbial flocs (Atkinson \& Daoud, 1975); microbial film (Atkinson \& Fowler, 1974); dental plaque (Newman \& Poole, 1974; Ellwood \& Hunter, 1976); the rhizosphere (Greenwood, 1971; Armstrong, 1975); the phylloplane (Ruinen, 1961); neuston (Harvey, 1966; Marshall, 1976; Romanko et al., 1978); the spermosphere (Lynch, 1978); and bacterial colonies (Pirt, 1967; Wimpenny \& Lewis, 1977; Wimpenny, 1979).

The complexity of ecosystems has hindered research in this area, but laboratory model systems may be important in simplifying and understanding them. However, few model systems are available. The addition of agar to an aqueous medium stabilizes the liquid against convection currents or mechanical movement, but allows almost unrestricted solute diffusion. Spray (1936) employed semi-solid media in order to identify clostridia as a result of their characteristic growth patterns under these conditions. Williams $(1938 a, b ; 1939 a, b)$ investigated the growth of many different species of bacteria in gel-stabilized media exposed to different partial pressures of oxygen or carbon dioxide. Banded growth patterns were observed and it was suggested that these bacterial 'spectra' might have a taxonomic value. 
Tschapek \& Gambiagi (1954) also observed banded growth in response to oxygen in gel-stabilized cultures of an Azotobacter sp. fixing nitrogen. Whittenbury (1963) used semi-solid agar to investigate those factors, particularly oxygen, that affected the utilization of fermentable substrates by lactic acid bacteria. Winogradsky columns (Winogradsky, 1949) and Perfil'ev capillaries (Perfil'ev \& Gabe, 1969) both produce solute gradients and led Caldwell \& Hirsch (1973) to develop a gel-stabilized system for studying the growth of micro-organisms in two-dimensional steady-state diffusion gradients. The system was used to cultivate various bacteria and to observe the responses of a natural community to environmental variation. Other model systems showing heterogeneity include percolating columns (discussed by Bazin et al., 1976), which have been used by various workers to investigate nitrogen cycle reactions in the soil. The estuarine ecosystem described by Cooper \& Copeland (1973) and the gradostat (Lovitt \& Wimpenny, 1979, 1981) have been used to generate heterogeneity in bidirectionally linked stirred vessels.

The present paper describes a method of investigating the growth of pure or mixed cultures in solute gradients established in aqueous nutrient media stabilized with agar.

\section{METHODS}

Organisms and maintenance. The following organisms were maintained on Dorset egg (Oxoid) slopes in the dark at room temperature: Bacillus megaterium NCTC 10342, Streptococcus faecalis NCTC 775, Escherichia coli K12, and Lactobacillus plantarum NCTC 1406, and Micrococcus luteus, Serratia indica and Bacillus sp. C19 (resembling Bacillus cereus) (the last three are from our departmental culture collection). The following were maintained on Tryptic Soy Broth (Difco) at $30 \mathrm{~g} \mathrm{I}^{-1}$ with agar (Difco) at $15 \mathrm{~g} \mathrm{l}^{-1}$, at $4{ }^{\circ} \mathrm{C}$ : Paracoccus denitrificans strains NCIB 8944, NCIB 9722, G16 and ATCC 13543, Bacillus cereus, Bacillus megaterium and Bacillus subtilis. Lactobacillus confusus NCIB 4037 was maintained at $4{ }^{\circ} \mathrm{C}$ in Casamino acids/yeast extract/salts (CYS) broth (see below) containing glucose.

Cultures of these organisms were grown overnight in 50 or $100 \mathrm{ml} \mathrm{CYS} \mathrm{broth} \mathrm{plus} \mathrm{glucose} \mathrm{at} 5 \mathrm{~g} \mathrm{l}^{-1}$ in 100 or $250 \mathrm{ml}$ conical flasks as follows: $\boldsymbol{M}$. luteus as a stationary culture at $25^{\circ} \mathrm{C} ; \boldsymbol{B}$. cereus as a stationary culture at $30^{\circ} \mathrm{C} ; L$. confusus anaerobically at $30^{\circ} \mathrm{C}$. The remaining organisms were shaken under aerobic conditions at $30^{\circ} \mathrm{C}$.

Inocula for the oil-based systems were obtained from the water bottoms of oil storage tanks (Esso Petroleum, Cardiff).

Media. CYS medium contained, in 11 distilled water: Casamino acids (Difco), $5.0 \mathrm{~g}$; yeast extract (Difco), $2.0 \mathrm{~g}$; and salts solution, $5 \mathrm{ml}$. The salts solution contained, in distilled water $\left(\mathrm{g} \mathrm{l}^{-1}\right): \mathrm{MgSO}_{4} .7 \mathrm{H}_{2} \mathrm{O}, 10.0$; $\mathrm{MnCl}_{2} .4 \mathrm{H}_{2} \mathrm{O}, 1 \cdot 0, \mathrm{FeSO}_{4} .7 \mathrm{H}_{2} \mathrm{O}, 0.4 ; \mathrm{CaCl}_{2} .6 \mathrm{H}_{2} \mathrm{O}, 0.2$, and a few drops of conc. $\mathrm{HCl}$ to clarify the solution. The $\mathrm{pH}$ of the medium was 6.4 before autoclaving. Glucose, sterilized as a $12 \%(\mathrm{w} / \mathrm{v})$ solution at $115^{\circ} \mathrm{C}$ for $10 \mathrm{~min}$, was added separately as described later. Sea-water medium (SW) contained in distilled water $\left(\mathrm{g} \mathrm{l}^{-1}\right): \mathrm{NaCl}$, $26.2 ; \mathrm{MgSO}_{4} .7 \mathrm{H}_{2} \mathrm{O}, 9.0 ; \mathrm{CaCl}_{2} \cdot 6 \mathrm{H}_{2} \mathrm{O}, 1.0 ; \mathrm{NH}_{4} \mathrm{Cl}, 1.0 ; \mathrm{KCl}, 0.7$. The $\mathrm{pH}$ of the medium was 7.8 before autoclaving. For viable count determinations, sea-water agar (SWA) (Difco) (ZoBell, 1941) and BushnellHaas/hexadecane agar (BHA/Hex) were used. BHA/Hex was prepared from Bushnell-Haas broth (Difco) solidified with $15 \mathrm{~g}$ purified agar (Difco) $\mathrm{l}^{-1}$. Hexadecane was introduced as a vapour from a sterile $9 \mathrm{~cm}$ filter paper saturated with hexadecane located in the Petri dish lid. All media were sterilized at $121^{\circ} \mathrm{C}$ for 15 min.

The standard gel-stabilized model system. The system was established in $250 \mathrm{ml}$ heat-sterilized glass beakers containing 100 or $120 \mathrm{ml} \mathrm{CYS} \mathrm{medium} \mathrm{supplemented} \mathrm{with} \mathrm{glucose} \mathrm{and} 1 \%(w / v)$ agar (Difco). Above this was poured a layer containing $120 \mathrm{ml}$ CYS medium supplemented with $0.4 \%(\mathrm{w} / \mathrm{v})$ agar well mixed with $1 \mathrm{ml}$ inoculum at $42 \pm 2{ }^{\circ} \mathrm{C}$. Each beaker, though covered with aluminium foil to maintain sterility, was open to the atmosphere and hence oxygen could diffuse into the upper layer. The system was incubated at an appropriate temperature for the stated time. Thus a semi-solid layer containing cells and basal medium lay above the 'source' layer which contained the same basal medium plus the diffusible solute - glucose.

The biphasic gel-stabilized model system. The second system was biphasic in that a layer of oil was located above a semi-solid layer containing organisms. The system was set up in $250 \mathrm{ml}$ heat-sterilized beakers containing a polished steel plate (approximately $3.8 \times 3.8 \times 0.1 \mathrm{~cm})$. SW medium $(125 \mathrm{ml})$ supplemented with $0.4 \%(\mathrm{w} / \mathrm{v})$ agar containing $0.5 \mathrm{ml}$ inoculum was allowed to set in the bottom of the beaker, and $125 \mathrm{ml}$ gas oil (diesel medium oil, Esso Petroleum) was poured over this layer.

Electrode methods. Needle electrodes for measuring $\mathrm{pH}, \mathrm{pO}_{2}$ or $E_{\mathrm{h}}$ were mounted on a Prior micromanipulator or modified microscope frame and lowered at measured intervals into the semi-solid agar layer. The $\mathrm{pH}$ was measured using a needle electrode (MI-405; Microelectrodes Inc., Londonderry, N.H., U.S.A.) with a calomel 
reference electrode connected via a $\mathrm{KCl}$ salt bridge to an ion analyser (model 801, Orion, Cambridge, Mass., U.S.A.). The oxygen tension ( $\mathrm{pO}_{2}$ ) was measured using a model $760-45^{\circ}$ needle electrode (Transidyne Inc., Ann Arbor, Mich., U.S.A.) and a $\mathrm{Ag} / \mathrm{AgCl}_{2}$ reference electrode connected to a Transidyne chemical microsensor. The redox potential $\left(E_{\mathrm{h}}\right)$ measurements were made using a bare platinum electrode and a calomel reference electrode connected via a $\mathrm{KCl}$ salt bridge to the Orion ion analyser.

Sampling the gels. A number 9 cork borer.was used to withdraw samples of each gel. The core was transferred to a gel slicer which cut $1 \mathrm{~mm}$ slices. Viable count determinations required the release of cells from the gel matrix. This was achieved using a Tefion and glass hand homogenizer; tests showed that 10-12 strokes were necessary to release the maximum number of cells. The cork borer, gel slicer and homogenizer were rinsed with $70 \%(v / v)$ ethanol and sterile tap water before use.

Growth estimation. Growth was estimated by measuring the $A_{550}^{1 \mathrm{~cm}}$ of the homogenized slice resuspended in buffer at $\mathrm{pH} 7.0$ or pH 7.4. Viable counts were determined using a spiral plater (Spiral Systems Inc., Cincinnati, Ohio, U.S.A.) (Gilchrist et al., 1973; Jarvis et al., 1977). Hexadecane utilizers were estimated on BHA/Hex medium. Anaerobic heterotrophs and sulphate-reducing bacteria were incubated anaerobically on SW agar; aerobic heterotrophs were incubated aerobically on the same medium. All viable count determinations were the mean of four separate measurements.

Chemical determinations. Glucose was measured enzymically using a Sigma glucose oxidase kit 510 following the method of Raabo \& Terkildsen (1960). Lactate was determined enzymically using a Sigma lactate dehydrogenase kit $826-\mathrm{UV}$ as described by Henry (1968). Iron was determined colorimetrically using thioglycollic acid (Department of the Environment, 1969). Sulphide was measured colorimetrically by the appearance of methylene blue from $p$-aminodimethylaniline hydrochloride in the presence of ferric ions (Johnson \& Nishita, 1952). All absorbance measurements were made on Pye-Unicam SP 1800 or MSE Spectro-plus spectrophotometers.

\section{RES ULTS}

Analysis of sampling procedures. Variation in counts obtained using the spiral plater was determined in replicate counts from a single $3 \mathrm{~mm}$ slice from one core. Cells were plated on to SWA and aerobic heterotrophs were counted after $7 \mathrm{~d}$ at $25^{\circ} \mathrm{C}$. Results for 20 counts indicated a standard deviation of $\pm 6.3 \%$ of the mean, which was $1.1 \times 10^{7}$ organisms $\mathrm{ml}^{-1}$. Variability between and within gel systems was determined by taking cores from 5 separate beakers and by counting the organisms 5 times in 5 slices from each core, making a total of 125 counts. The results are shown in Table 1. Variation between similar slices from different gels was $11-35 \%$ and for replicate counts from the same gel $6.3 \%$. There are two possible sources of error: in slicing and counting from a single core, and in inherent differences between duplicate gel systems. Bartlett's test of homogeneity of variances (Bailey, 1959) showed the differences between gel systems to be insignificant compared with the variation within each gel system. The major source of error was due to gel slicing. If the standard deviation between individual slices taken from 25 cores is compared, the variation omitting the initial slice is between 11 and $17 \%$ of the mean of the count instead of the value of $35 \%$ obtained if the initial slice is included. Error was probably due to the difficulty in accurately determining the position of the core surface during slicing.

Growth of Bacillus megaterium NCTC 10342 in the standard gel system. Using CYS medium with the addition of $2 \%(\mathrm{w} / \mathrm{v})$ glucose in the source layer, the standard gel system was used to investigate the growth of the aerobe Bacillus megaterium NCTC 10342. Test and uninoculated controls were established and incubated at $30^{\circ} \mathrm{C}$ for $5 \mathrm{~d}$. The control results showed that the $\mathrm{pH}$ was 5.95 throughout the system and the $E_{\mathrm{h}}$ remained close to $+400 \mathrm{mV}$. Oxygen and glucose gradients were established as indicated in Fig. $1(a)$.

The inoculated system (Fig. $1 b$ ) showed extensive growth at the surface with absorbance values decreasing as depth increased. The $\mathrm{pH}$ values ranged from 7.5 near the surface to 7.0 at the bottom of the semi-solid layer. This indicated alkalinization due to the growth of the micro-organism. The $E_{\mathrm{h}}$ values were more negative than the control values, falling from +76 $\mathrm{mV}$ at the surface to a minimum of $0 \mathrm{mV} 16 \mathrm{~mm}$ below the surface, but the $E_{\mathrm{h}}$ rose to $+16 \mathrm{mV}$ near the bottom of the semi-solid layer. In the inoculated gel no glucose was detected 
Table 1. Reliability of sampling and counting gel systems

Five counts were made from the first five slices of cores taken from five separate gel systems.

\begin{tabular}{|c|c|c|c|c|c|}
\hline & \multicolumn{5}{|c|}{$10^{-6} \times$ No. of organisms $\mathrm{ml}^{-1}$ in each slice } \\
\hline & $\begin{array}{c}\text { Slice } 1 \\
(0-3 \mathrm{~mm})\end{array}$ & $\begin{array}{c}\text { Slice } 2 \\
(3-6 \mathrm{~mm})\end{array}$ & $\begin{array}{c}\text { Slice } 3 \\
(6-9 \mathrm{~mm})\end{array}$ & $\begin{array}{c}\text { Slice 4 } \\
(9-12 \mathrm{~mm})\end{array}$ & $\begin{array}{c}\text { Slice } 5 \\
(12-15 \mathrm{~mm})\end{array}$ \\
\hline Gel 1 & $\begin{array}{l}4.42 \\
4.66 \\
6 \cdot 80 \\
4.24 \\
4 \cdot 13\end{array}$ & $\begin{array}{r}8.56 \\
10.32 \\
10.80 \\
9.28 \\
7.44\end{array}$ & $\begin{array}{c}8.4 \\
11.92 \\
11.28 \\
9.36 \\
10.16\end{array}$ & $\begin{array}{r}11 \cdot 28 \\
11 \cdot 28 \\
11.44 \\
8 \cdot 72 \\
12.08\end{array}$ & $\begin{array}{r}11.28 \\
9.96 \\
9.68 \\
8.80 \\
10.72\end{array}$ \\
\hline Gel 2 & $\begin{array}{l}6.32 \\
7.28 \\
7.84 \\
9.60 \\
4.42\end{array}$ & $\begin{array}{r}9.92 \\
12.48 \\
10 \cdot 72 \\
11.20 \\
11.20\end{array}$ & $\begin{array}{l}12.08 \\
12.72 \\
11.20 \\
11.60 \\
12.80\end{array}$ & $\begin{array}{r}9.36 \\
11.36 \\
12.08 \\
12.96 \\
12.00\end{array}$ & $\begin{array}{r}10 \cdot 24 \\
10.40 \\
6.08 \\
9 \cdot 52 \\
10.40\end{array}$ \\
\hline Gel 3 & $\begin{array}{r}4.98 \\
6.00 \\
5.62 \\
5.44 \\
10.32\end{array}$ & $\begin{array}{l}10.88 \\
10 \cdot 0 \\
10.72 \\
12.08 \\
12 \cdot 88\end{array}$ & $\begin{array}{l}11.04 \\
11.52 \\
12.48 \\
10.72 \\
12.24\end{array}$ & $\begin{array}{r}11.92 \\
12.56 \\
13.36 \\
5.52 \\
12.72\end{array}$ & $\begin{array}{c}6 \cdot 8 \\
11 \cdot 36 \\
11 \cdot 44 \\
9 \cdot 92 \\
9 \cdot 60\end{array}$ \\
\hline $\mathrm{Gel} 4$ & $\begin{array}{r}12.24 \\
9.60 \\
8.60 \\
8.16 \\
10.00\end{array}$ & $\begin{array}{r}11.44 \\
11.92 \\
12.80 \\
9.36 \\
10.24\end{array}$ & $\begin{array}{c}11 \cdot 60 \\
13 \cdot 12 \\
13.44 \\
\mathrm{NT} \\
10 \cdot 80\end{array}$ & $\begin{array}{c}10 \cdot 80 \\
13 \cdot 36 \\
11 \cdot 19 \\
\text { NT } \\
10 \cdot 80\end{array}$ & $\begin{array}{c}11.76 \\
\text { NT } \\
12 \cdot 16 \\
10 \cdot 40 \\
10 \cdot 24\end{array}$ \\
\hline Gel 5 & $\begin{array}{c}11.7 \\
2.00 \\
8.90 \\
9.52 \\
9.04\end{array}$ & $\begin{array}{c}11.04 \\
12.04 \\
9.44 \\
8.08 \\
12.4\end{array}$ & $\begin{array}{r}11 \cdot 12 \\
11 \cdot 36 \\
12 \cdot 48 \\
9 \cdot 68 \\
13 \cdot 36\end{array}$ & $\begin{array}{c}13 \cdot 28 \\
12.40 \\
\text { NT } \\
10 \cdot 56 \\
11.28\end{array}$ & $\begin{array}{c}13 \cdot 5 \\
9 \cdot 12 \\
10 \cdot 72 \\
14 \cdot 24 \\
11 \cdot 20\end{array}$ \\
\hline $\begin{array}{l}\text { Total no. of slices } \\
10^{-6} \times \text { Mean count } \\
10^{-6} \times \text { S.D. } \\
\text { S.D. as \% of mean } \\
\text { Bartlett's test }\end{array}$ & $\begin{array}{c}25 \\
7.07 \\
2.50 \\
35.4 \% \\
5.85\end{array}$ & $\begin{array}{c}25 \\
10 \cdot 71 \\
1.47 \\
13 \cdot 7 \% \\
3 \cdot 35\end{array}$ & $\begin{array}{c}24 \\
11 \cdot 56 \\
1.27 \\
11.0 \% \\
3.15\end{array}$ & $\begin{array}{c}23 \\
11 \cdot 45 \\
1 \cdot 71 \\
14.9 \% \\
3 \cdot 37\end{array}$ & $\begin{array}{c}24 \\
10 \cdot 35 \\
1 \cdot 78 \\
17 \cdot 2 \% \\
3 \cdot 60\end{array}$ \\
\hline
\end{tabular}

at the surface but glucose was detected at all depths below $7 \mathrm{~mm}$ and the $\mathrm{pO}_{2}$ dropped to zero at a depth of $3 \mathrm{~mm}$ from the surface.

Growth of Lactobacillus confusus NCIB 4037 in the standard gel system. Using CYS medium with the addition of $2 \%(\mathrm{w} / \mathrm{v})$ glucose in the source layer, the standard gel system was used to study the growth of the microaerophilic lactic acid bacterium Lactobacillus confusus NCIB 4037. Control and test gels were established and each was incubated for 4 or $5 \mathrm{~d}$ at $30^{\circ} \mathrm{C}$.

The $\mathrm{pH}$ of the uninoculated control ranged from 6.5 at the surface to 6.3 at the bottom of the semi-solid layer (Fig. $2 a$ ). In the inoculated system, the pH fell from 4.8 at the surface to 4.0 near the source layer (Fig. $2 b$ ). The low pH reflected the fact that this organism fermented glucose to lactic acid. A gradient of $\mathrm{pO}_{2}$ was seen through the control system with measurable values to a depth of $30 \mathrm{~mm}$ (Fig. $2 a$ ). In contrast, the $\mathrm{pO}_{2}$ fell to zero within $3 \mathrm{~mm}$ of the surface in the inoculated system (Fig. $2 b$ ). Although unable to derive energy from respiration, many lactic acid bacteria are capable of growth in the presence of some oxygen and are also capable of flavoprotein-mediated respiration.

Absorbance measurements showed extensive growth at the bottom of the semi-solid layer nearest the glucose source. There was no surface growth, but two discrete bands of growth 

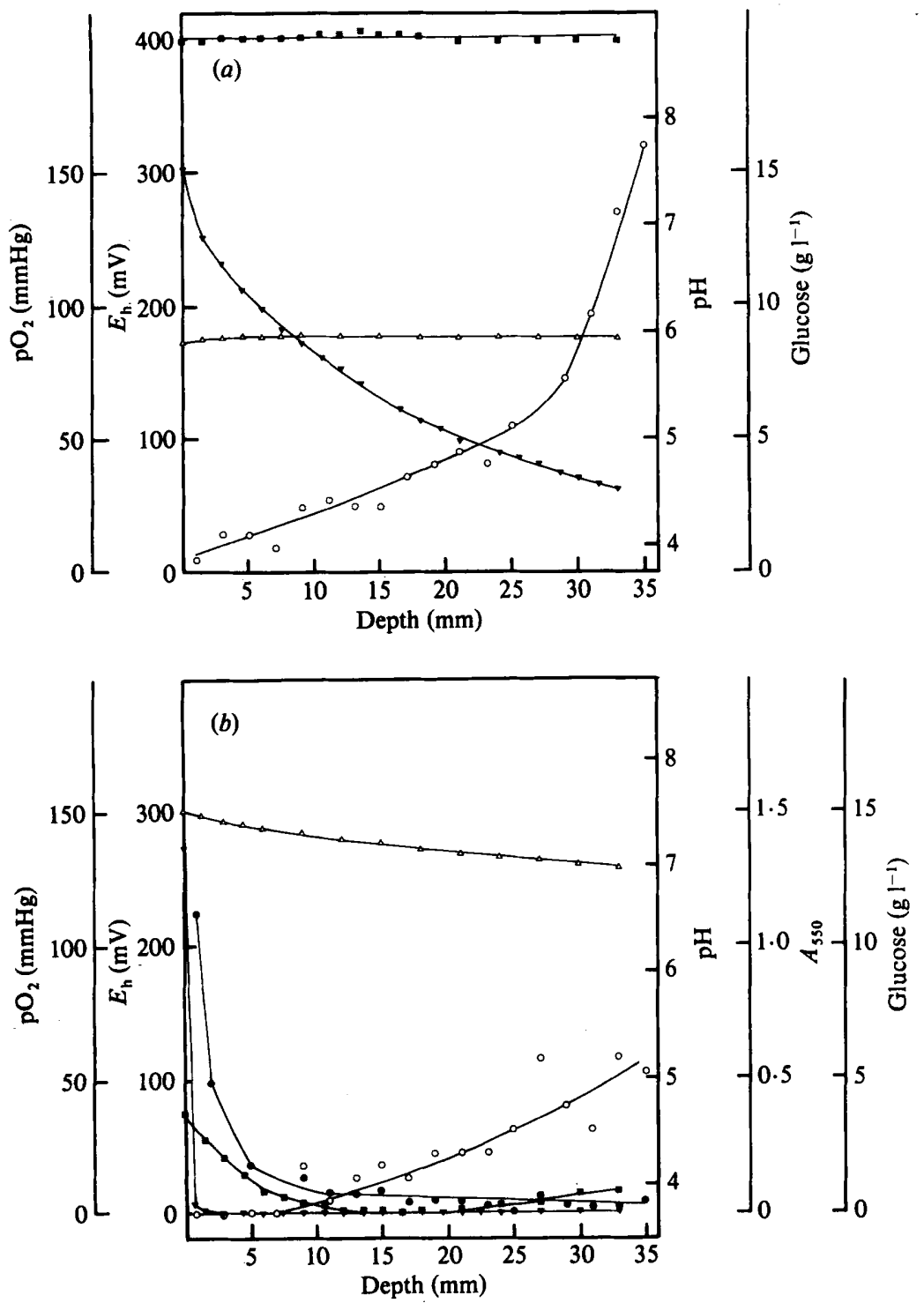

Fig. 1. Physicochemical environment in (a) an uninoculated standard gel system incubated at $30^{\circ} \mathrm{C}$ for $5 \mathrm{~d}$, and $(b)$ a similar gel system inoculated with Bacillus megaterium NCTC 10342 and incubated at $30^{\circ} \mathrm{C}$ for 5 d. $\triangle, \mathrm{pH} ; \nabla, \mathrm{pO}_{2} ; \square, E_{\mathrm{h}} ; \mathrm{O}$, glucose;,$A_{550}$. The interface between the two layers was at $36 \mathrm{~mm}$ depth.

appeared 1 and $6 \mathrm{~mm}$ below the surface. Gradients of glucose and of lactic acid were apparent throughout the semi-solid layer.

The low $\mathrm{pH}$ values and high residual glucose concentrations in this experiment suggested that a lower glucose concentration in the source ought to be investigated. Such an experiment indicated that quite steep $\mathrm{pH}$ gradients could be generated at appropriate glucose concentrations (Fig. 3). If the glucose concentration was too high the gel became acid throughout; if it was too low there was little change in $\mathrm{pH}$ from values in the control system.

Growth patterns for different species of bacteria. The results with $L$. confusus suggested that other species might also generate band patterns when cultivated on CYS medium in the standard gel-stabilized system. In all cases glucose $(2 \%, w / v)$ was used in the source layer. A 

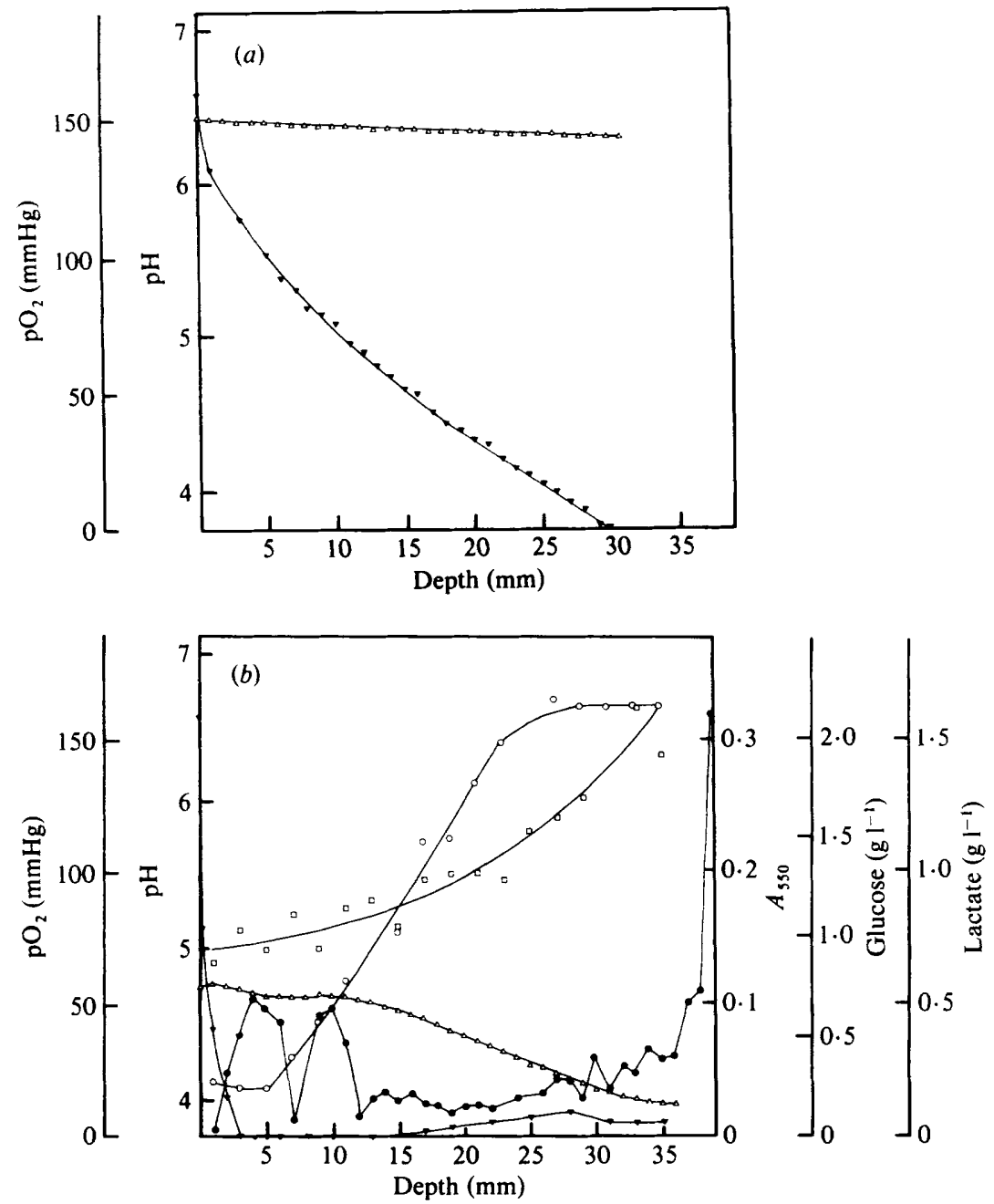

Fig. 2. Physicochemical environment in (a) an uninoculated standard gel system incubated at $30^{\circ} \mathrm{C}$ for $4 \mathrm{~d}$, and (b) a similar gel system inoculated with Lactobacillus confusus NCIB 4037 and incubated at $30^{\circ} \mathrm{C}$ for $4-5$ d. $\triangle, \mathrm{pH} ; \nabla, \mathrm{pO}_{2} ; O, A_{s s 0} ; \mathrm{O}$, glucose concentration; $\square$, lactate concentration.

total of 15 strains were examined. All grew on the surface with the exception of $L$. confusus and the results showed three different types of effect (Table 2). Some organisms never produced bands; some produced bands occasionally; and some always produced a varying number of bands. Band positions were calculated as $R_{\mathrm{b}}$ values, defined as the height of the band above the junction between the source and semi-solid layers divided by the depth of the semi-solid layer. The band-forming organisms were all capable of anaerobic growth. The non-band-forming organisms were aerobes with the exception of L. plantarum. Two strains of Paracoccus denitrificans occasionally showed faint bands. The organisms which showed the most extensive band development were Bacillus cereus and a laboratory isolate (strain C19) which was tentatively identified as $B$. cereus (Fig. 4). Up to eight separate bands were seen under appropriate conditions when $B$. cereus was grown in the standard gel-stabilized system. Band formation in cultures of $B$. cereus was sequential. The following observations were made: band formation was preceded by surface growth; the first band appeared lowest of all the major bands in the gel; subsequent bands appeared between this band and the surface; 


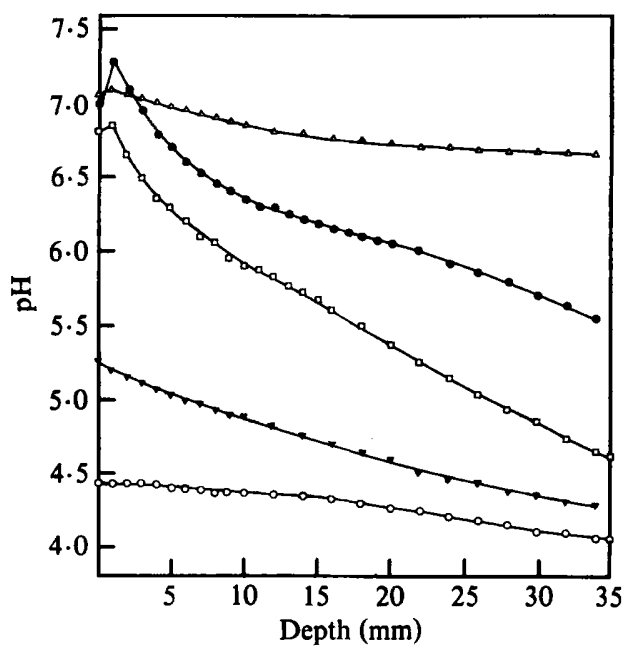

Fig. 3. pH profiles in standard gel systems inoculated with Lactobacillus confusus NCIB 4037, after incubation at $30^{\circ} \mathrm{C}$ for $5 \mathrm{~d}$. The five systems contained different concentrations of glucose in the lower layer: $0 \%(w / v)(\triangle) ; 0.25 \%(O) ; 0.5 \%(\square) ; 1.0 \%(\nabla)$; and $2.0 \%(O)$.

\section{Table 2. Band formation by various species of bacteria grown in the gel system}

The position of any one band is expressed as an $R_{\mathrm{b}}$ value, that is, the height of the band from the bottom of the semi-solid layer, divided by the depth of the semi-solid layer.

Growth pattern

Bands produced

Bands not produced

Bands produced occasionally
Organism

Serratia indica

Streptococcus faecalis NCTC 775

Escherichia coli $\mathrm{K} 12$

Bacillus sp. C19

Bacillus subtilis

Bacillus cereus

Bacillus megaterium

Lactobacillus confusus NCIB 4037

Micrococcus luteus

Lactobacillus plantarum NCTC 1406

Paracoccus denitrificans NCIB 8944

Paracoccus denitrificans NCIB 9722

Bacillus megaterium NCTC 10342

Paracoccus denitrificans G16

Paracoccus denitrificans ATCC 13543
Band position ( $R_{\mathrm{b}}$ value $)^{*}$

SG, $0.61,0.47,0.42$

SG, $0.78,0.56$

SG, 0.53

SG, $0.81,0.75,0.69,0.61,0.47$

SG, $0.83,0.81,0.64$

SG, $0.75,0.69$

SG, $0.69,0.61$

$0.97,0.83$

SG only

SG only

SG only

SG only

SG only

SG only or SG, 0.78

SG only or SG, 0.53

* SG, Surface growth.

during the course of the experiment, the bands remained in position; in systems incubated for longer than $6 \mathrm{~d}$ faint bands appeared at lower positions in the gel.

The biphasic gel-stabilized system. The biphasic gel-stabilized system was used to model microbial growth in the water base of oil storage tanks. Control and test gels were set up and incubated for up to $90 \mathrm{~d}$. The presence of the steel plate led to the development of coloured bands which acted as markers of oxygen penetration. The bands were probably produced as follows: soluble ferrous salts diffused upwards in the gel meeting oxygen diffusing down from the surface. At this point orange ferric salts precipitated as a band. Results from the test gel incubated for $90 \mathrm{~d}$ (Fig. $5 \mathrm{~b}$ ) showed two peaks of iron, one at the point where oxygen disappeared, and a second near the steel plate surface. Sulphide, generated by sulphatereducing bacteria, was found only at the bottom of the gel close to the steel plate. $E_{\mathrm{h}}$ showed a 


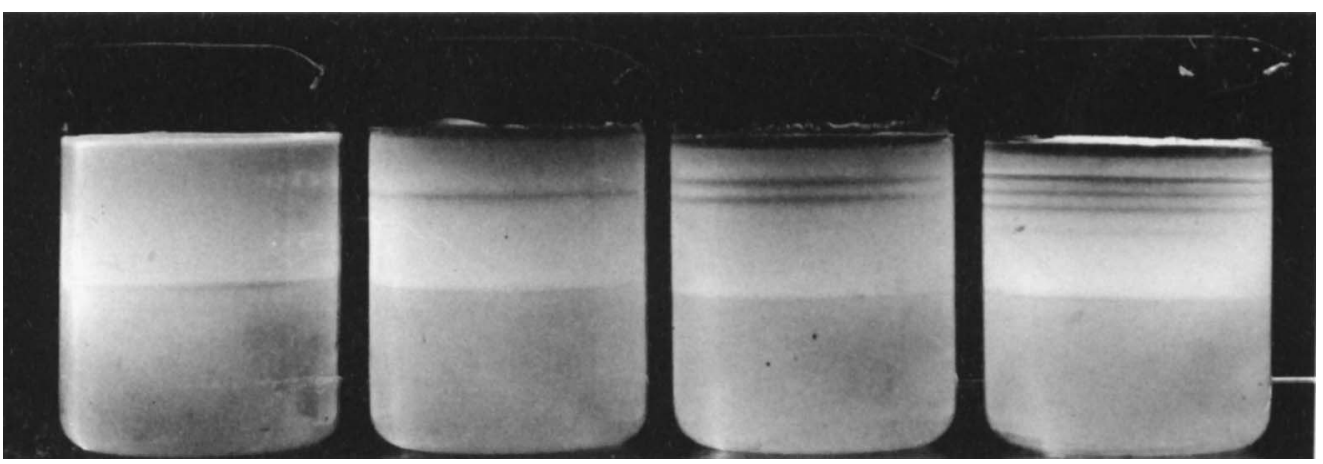

Fig. 4. Development of bands in a standard gel system inoculated with Bacillus sp. C19 incubated at $30^{\circ} \mathrm{C}$, showing the system at (left to right) $0,2,4$ and $6 \mathrm{~d}$.
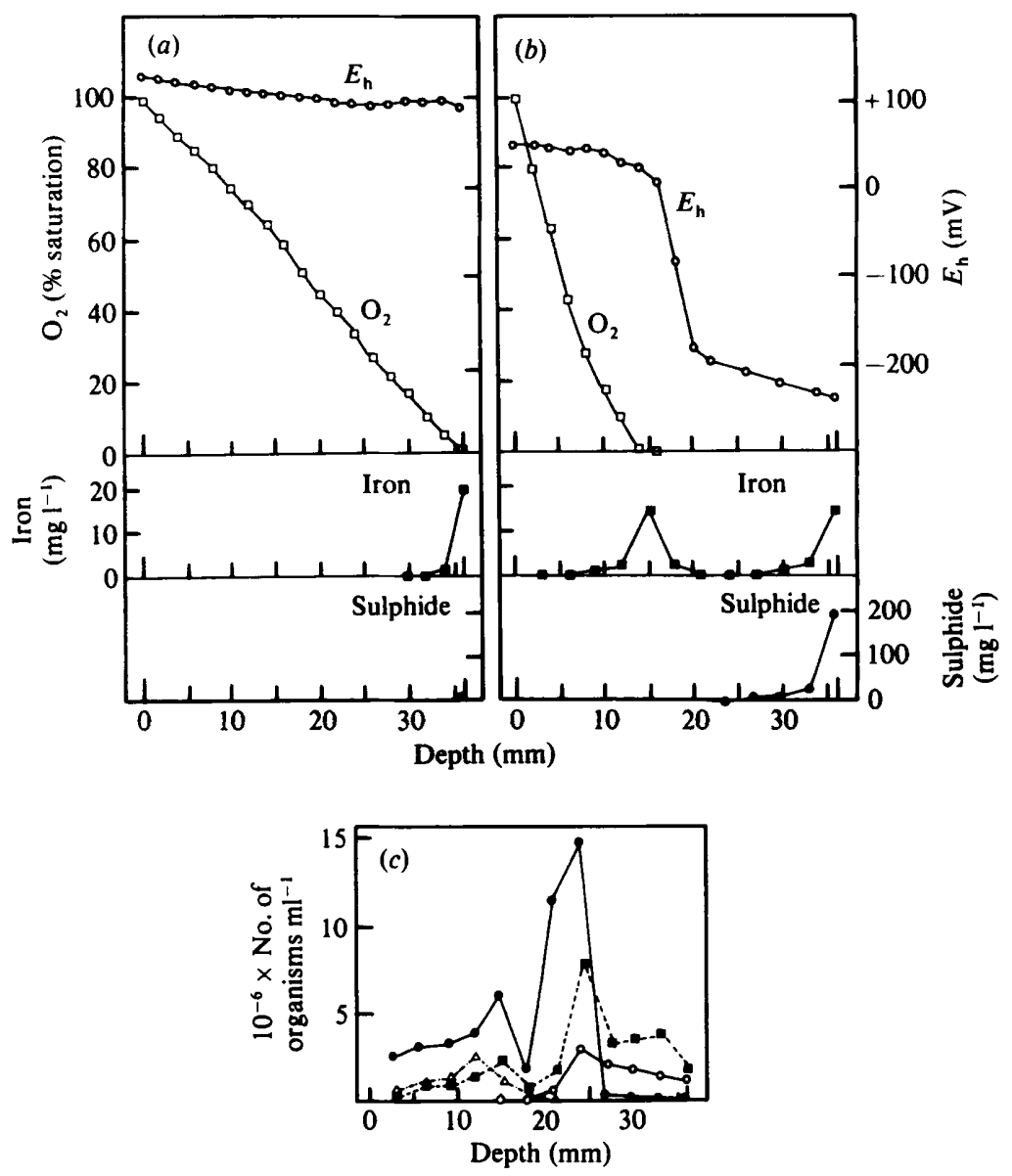

Fig. 5. $(a, b)$ Physicochemical environment in $(a)$ an uninoculated control biphasic gel system after incubation at $25^{\circ} \mathrm{C}$ for $90 \mathrm{~d}$. and $(b)$ a similar svstem inoculated from the water bottom of an oil storage tank, after incubation at $25^{\circ} \mathrm{C}$ for $90 \mathrm{~d} . \square, \mathrm{pO}_{2} ; O, E_{\mathrm{h}} ; \square$, iron concentration; $O$, sulphide concentration. (c) Microbial profiles through the inoculated system, showing aerobic heterotrophs (O); anaerobic heterotrophs $(\square)$; hexadecane utilizers $(\Delta)$ and sulphate-reducing bacteria $(O)$. 
maximum rate of change from positive to negative values in the area where oxygen became limiting. Sulphate-reducing bacteria were only present in the anaerobic region below $20 \mathrm{~mm}$ depth and the aerobic hexadecane oxidizers were only present in the aerobic region above about $15 \mathrm{~mm}$. There were heterogeneous populations of aerobic and anaerobic heterotrophs distributed as indicated in Fig. 5(c). Examination of uninoculated control gels incubated for the same period showed that in the absence of organisms solute gradients still appeared (Fig. $5 a$ ). Thus oxygen was reduced by the steel plate, generating an oxygen gradient down the gel. There was no detectable sulphide. $E_{\mathrm{h}}$ changed only slightly and there was detectable iron at the base of the gel.

\section{DISCUSSION}

All organisms occupy space in nature. In some cases spatial coordinates are not fixed and environmental conditions may be uniform or homogeneous. This applies to laboratory microcosms like the chemostat. In other cases organisms spend at least part of their existence at fixed positions, proliferating in solute gradients. The complexity of natural ecosystems showing spatial organization has discouraged research in this area, and there is a need for laboratory models which are simple enough to reveal some of the fundamental properties of such systems.

The addition of a gelling agent to a liquid culture medium prevents mechanical motion of the bulk of the liquid or of cells whilst offering only small additional increase in diffusion resistance to solute flow. The model described in this paper is based on this principle and is easy to establish and reproducible in its characteristics. Measurement of growth and analysis of the gel composition requires only the removal, slicing and analysis of gel cores. Viable count determinations in replicate samples from the same gel proved highly reproducible and the system had a low coefficient of variation from experiment to experiment. Electrode measurements allowed an accurate assessment of $\mathrm{pH}, \mathrm{pO}_{2}$ and $E_{\mathrm{h}}$ in each gel. The incorporation of isotopes into the system has not yet been tried, but ought to increase chemical resolution if used with gas-liquid chromatography or high-pressure liquid chromatography coupled to isotope flow counters.

The technique used to inoculate the semi-solid layer of these systems ensured that initially cells were dispersed evenly throughout the layer. During growth the system differentiated as cells grew in response to changing physicochemical conditions. Some of these environmental factors have been documented for cultures of Bacillus megaterium and of Lactobacillus confusus.

Of a variety of bacterial species or strains examined, most grew best at the surface of a Casamino acids/yeast extract/salts gel in which glucose was the diffusing solute. In many cases, organization of the gel space led to the development of bands of growth in the agar. The appearance of such periodic structures has as yet no satisfactory explanation, but may be related to other gel diffusion phenomena reported in the literature. Thus the diffusion of silver nitrate in gels containing traces of potassium dichromate leads to the formation of multiple discrete bands of precipitate called Liesegang rings (Liesegang, 1896). Similar structures are also observed in immunological precipitin reactions under conditions where there is a large excess of one of the reactants (Crowle, 1973). Banded growth in the gel system may be dependent on two essential nutrients diffusing towards one another in opposite directions. Once growth takes place, perhaps at the interface between the two, newly formed cells will constitute a sink for both solutes. The solute present in the lowest concentration may virtually disappear in the region adjacent to the growth zone, preventing further growth. The second solute may then diffuse across this zone to regions where the limiting solute is once more available and further growth may occur. This explanation is essentially speculative at present. Further work is under way and includes an attempt to simulate banded growth using a numerical model. 
The model of an oil storage tank water base provides a good illustration of the value of the gel system for investigating interactions in ecosystems which are too difficult to investigate in situ. Sampling of the water layer of an oil storage tank is accomplished either through a drain cock at the base of the tank, or by lowering a tube into the water layer and withdrawing a sample. In both cases, spatial heterogeneity is lost, and an assessment of oxygen-sensitive bacteria present will be influenced by the mixing of aerobic and anaerobic layers. The gel-stabilized model overcomes these problems and the model demonstrates how the water base ecosystem could organize itself in the absence of mechanical disturbances. Some of the interactions which probably occur in the biphasic model include the protection of anaerobes due to the removal of oxygen by hydrocarbon oxidizers and aerobic heterotrophs; mobilization of hydrocarbons as the primary energy and carbon source for the whole system by hydrocarbon-oxidizing bacteria; reduction of sulphate to sulphide by sulphate-reducing bacteria; and re-oxidation of the sulphide by aerobic sulphur-oxidizing bacteria.

The gel-stabilized systems described here are closed for cells and for solutes with the exception of atmospheric gas exchange. The presence of growing cells means that no true solute steady state exists. The gel systems therefore are ideally suited to the investigation of transient conditions such as the sequence of events that take place when a microbial species colonizes a new environment. There are a number of areas in which gel-stabilized models appear to have potential. These include delineating habitat requirements for particular strains or species of bacteria; the establishment of conditions in which growth, particularly banded growth, can be used as a taxonomic aid; and the investigation of interactions between pairs or groups of bacteria.

The authors gratefully acknowledge grants from the S.R.C. supporting J.P.C. and from Esso Research Ltd to R.W.L.

\section{RE FEREN CES}

ARMSTronG, W. (1975). Waterlogged soils. In Environmental and Plant Ecology, pp. 181-218. Edited by J. R. Etherington. London: Wiley.

AtKinson, B. \& Daoud, I. S. (1975). Microbial flocs and flocculation in fermentation process engineering. Advances in Biological Engineering 4, 41-124.

AtKInson, B. \& Fowler, H. W. (1974). The significance of microbial film in fermenters. Advances in Biological Engineering 3, 221-277.

BaILEY, N. T. J. (1959). Statistical Methods in Biology. London: English University Press.

Bazin, M. J., Saunders, P. T. \& Prosser, J. I. (1976). Models of microbial interaction in the soil. CRC Critical Reviews in Microbiology 4, 463498.

Caldwell, D. E. \& Hirsch, P. (1973). Growth of microorganisms in two-dimensional steady-state diffusion gradients. Canadian Journal of Microbiology 19, 53-58.

Chebotarev, E. N., Gorlenko, V. M. \& KACHALKIN, V. I. (1974). Microbiological hydrogen sulphide formation in Lake Repnoe (Slavyansk Lakes). Microbiology (English translation of Mikrobiologiya) 42, 475-479.

CoOper, D. C. \& Copeland, B. J. (1973). Responses of a continuous series of estuarine microecosystems to point-source input variations. Ecological Monographs 43, 213-236.

Crowle, A. J. (1973). Immunodiffusion, 2nd edn. London: Academic Press.
Deevey, E. S. (1951). Life in the depths of a pond. Scientific American 185, 68-72.

DePARTMENT OF THE ENVIRONMENT (1969). Analysis of Raw, Potable and Waste Water. London: H.M.S.O.

EllwoOd, D. C. \& HUNTER, J. R. (1976). The mouth as a chemostat. In Continuous Culture 6: Application and New Fields, pp. 270-272. Edited by A. C. R. Dean, D. C. Ellwood, C. G. T. Evans \& J. Melling. Chichester, England: Ellis Harwood.

Gilchrist, J. E., Campbell, J. E., Donnelly, C. B. DeEler, J. T. \& Delany, J. M. (1973). Spiral plate method for bacterial determination. Applied Microbiology 25, 244-252.

GREENWOOD, D. J. (1971). Studies on the distribution of oxygen around mustard seedlings (Sinapis alba L.). New Phytologist 70, 97-101.

HaRvey, G. W. (1966). Microlayer collection from the sea surface: a new method and initial results. Limnology and Oceanography 11, 608-613.

Henry, R. J. (1968). Clinical Chemistry - Principles and Technics, pp. 664-666. New York: Harper \& Row.

JaRvis, B., Lach, V. H. \& WoOd, J. M. (1977). Evaluation of the spiral plate maker for the enumeration of micro-organisms in foods. Journal of Applied Bacteriology 43, 149-157.

Johnson, C. M. \& Nishita, M. (1952). Microestimation of sulphur in plant materials, soils and irrigation waters. Analytical Chemistry 24, 736-742. 
Jgrgensen, B. B., Revsbech, N. P., Blackburn, T. H. \& CoHEN, Y. (1979). Diurnal cycle of oxygen and sulphide microgradients and microbial photosynthesis in a cyanobacterial mat sediment. Applied and Environmental Microbiology 38, 46-58.

LIESEGANG, R. E. (1896). Ueber einige Eigenschaften von Gallerten. Naturwissenschaftliche Wochenschrift 11, 353-362.

LovitT, R. W. \& Wimpenny, J. W. T. (1979). The gradostat: a tool for investigating microbial growth and interactions in solute gradients. Society for General Microbiology Quarterly 6, 80.

LovitT, R. W. \& WIMPENNY, J. W. T. (1981). The gradostat: a bidirectional compound chemostat and its application in microbiological research. Journal of General Microbiology 127, 261-268.

LYNCH, J. M. (1978). Microbial interaction around imbibed seeds. Annals of Applied Biology 89, 165-167.

MARshall, K. C. (1976). Interfaces in Microbial Ecology. London: Harvard University Press.

Mortimer, C. H. (1942). The exchange of dissolved substances between mud and water in lakes. Journal of Ecology 30, 147-201.

Newman, H. N. \& Poole, D. F. G. (1974). Structural and ecological aspects of dental plaque. In The Natural Microbial Flora of Man, pp. 111-134. Edited by F. A. Skinner \& J. G. Carr. London: Academic Press.

Perfil'ev, B. V. \& Gabe, D. R. (1969). Capillary Methods of Investigating Micro-organisms (English translation). Edinburgh: Oliver \& Boyd.

PIRT, S. J. (1967). A kinetic study of the mode of growth of surface colonies of bacteria and fungi. Journal of General Microbiology 47, 181-197.

RaAbo, E. \& Terkildsen, T. C. (1960). On the enzymatic determination of blood glucose. Scandinavian Journal of Clinical and Laboratory Investigation 12, 402-407.

Romanko, V. I., Pubienes, M. A. \& Daukshta, A. S. (1978). Growth and activity of bacteria on the surface film of water under experimental conditions. Microbiology (English translation of Mikrobiologiya) 47, 119-125.
RUINEN, J. (1961). The phyllosphere. I. An ecologically neglected milieu. Plant and Soil 15, 81-109.

SorokIN, Y. I. (1968). Primary production and microbiological processes in Lake Gek Gel. Microbiology (English translation of Mikrobiologiya) 37, 289-296.

SPRAY, R. S. (1936). Semisolid media for cultivation and identification of the sporulating anaerobes. Journal of Bacteriology 32, 135-155.

Stanley, S. O. \& MalColm, S. (1980). The sediment environment. Society for General Microbiology Quarterly 7,64.

TsCHAPEK, M. \& Gambiagi, N. (1954). Die Bildung von Liesegang'schen Ringen durch Azotobacter bei $\mathrm{O}_{2}$-hemmung. Kolloidzeitschrift 135, 47-48.

WhITTENBURY, R. (1963). The use of soft agar in the study of conditions affecting the utilization of fermentable substrates by lactic acid bacteria. Journal of General Microbiology 32, 375-384.

Williams, J. W. $(1938 a)$. Bacterial growth "spectrum" analysis. I. Methods and application. American Journal of Medical Technology 4, 58-61.

Williams, J. W. (1938b). Bacterial growth "spectrum" analysis. II. Their significance in pathology and bacteriology. American Journal of Pathology 14, 642-645.

Williams, J. W. $(1939 a)$. The nature of gel mediums as determined by various gas tensions and its importance in growth of microorganisms and cellular metabolism. Growth 3, 181-196.

Williams, J. W. $(1939 b)$. Growth of microorganisms in shake cultures under increased oxygen and carbon dioxide tensions. Growth 3, 21-33.

WIMPENNY, J. W. T. (1979). The growth and form of bacterial colonies. Journal of General Microbiology $114,483-486$.

WimpenNy, J. W. T. \& LeWIS, M. W. A. (1977). The growth and respiration of bacterial colonies. Journal of General Microbiology 103, 9-18.

Winogradsky, S. (1949). Microbiologie du Sol. Paris: Masson.

ZoBell, C. E. (1941). Studies on marine bacteria. I. Cultural requirements for heterotrophic aerobes. Journal of Marine Research 4, 42-47. 